\title{
Hygienic Habits and Living Conditions of Romani Population in the Sisak-Moslavina County
}

1 Snježana Galić Lukšić

2 Goran Lapat

${ }^{3}$ Jelena Lučan

1 General Hospital Sisak, Department of Pediatrics, Sisak, Croatia

2 Faculty of Teacher Education, University of Zagreb, Zagreb, Croatia

${ }^{3}$ Viktorovac High School, Sisak, Croatia

Article received: 26.09.2020.

Article accepted: 23.10 .2020 .

https://doi.org/10.24141/2/4/2/3

Author for correspondence:

Jelena Lučan

Viktorovac High School

Aleja narodnih heroja 1, Sisak, Croatia

E-mail: jjokic1@gmail.com

Keywords: hygiene habits, children's respiratory diseases, Romani population

\section{Abstract}

Aim. To establish the degree of consciousness of the importance of hygiene among the Romani population in the Sisak-Moslavina County and to examine whether there are differences in children's health care of non-Romani population considering the number of hospitalized Romani children in general and especially regarding respiratory diseases.

Methods. The study was conducted on 100 parents of hospitalized children, 50 of them being members of the Romani population and 50 being members of non-Romani population. It was done by means of a questionnaire specially designed for this study. The categorical data is represented by the absolute and relative frequencies, while the numerical data is described with the median and the limits of the interquartile span. Categorical variable differences were tested using Fisher's exact test. The normality of numerical variable distribution was tested using the Shapiro-Wilk test. The differences in numerical variables between two independent groups were tested using the Mann-Whitney $U$ test.

Results. The results show that due to respiratory diseases a significantly large number of Romani children $(43 \%)$ were hospitalized once in six months. Fewer children of Romani research subjects who have indoor plumbing were hospitalized. Romani families tend to visit a doctor when a child is injured or for a regular check-up rather than to seek a doctor's advice. In non-Romani families, children tend to shower every day, have their own towel and better personal hygiene habits than children of Romani families. The 
results clearly show hygiene habits differ greatly between Romani and non-Romani families. Neglecting their children's personal hygiene habits in Romani families points to a problem of insufficient education of the parents.

Conclusion. The obtained results point to the importance of constant encouragement and education of Romani family members, as well as the members of non-Romani families, in order for them to realize the significance of hygiene and personal hygiene habits.

\section{Introduction}

The Roma are traditionally a nomadic people typical for their customs, non-unified religious affiliation, and a tumultuous history, as well as significant differences in social, educational and hygiene habits, especially in Croatia (1). Today, in the territory of the Republic of Croatia there are scattered Romani settlements. Still, the greatest concentration is found in the territories of several counties, namely the City of Zagreb, Koprivnica-Križevci County, Sisak-Moslavina County, Međimurje County and Osijek-Baranja County. According to the latest census, 9,463 declared members of that national minority currently reside in Croatia, but it is estimated that there are in total between 30 and 40 thousand Roma.

The lack of precise data on the number of members of the Romani national minority and the unavailability of information only increase the opportunities for the Roma to be denied their rights and thus further marginalized. Poverty, low level of education, and poor motivation for education are the primary aspects of Romani's endangerment. Lapat and Šlezak (2010) point out that the Roma are the ethic group least integrated in contemporary Croatian society, for which they provide two reasons. The first relates to severe prejudice and stereotypical attitudes of the local population. The other relates to the fact that the Roma are people who are not prone to easily changing their lifestyle due to tradition, which plays a very important role in their lives (2).

The Republic of Croatia ensures equal rights to members of all national minorities in accordance with the highest international standards and in line with international conventions and other documents on human rights and the rights of national minorities which are built into the Constitution of the Republic of Croatia, Constitutional law on the rights of national minorities and other legal acts regulating the right and protection of national minorities (3). National Programme for the Roma provides good conditions and opportunities for medical education directed at the Romani population. Apart from that, other areas of concern and work are eliminating poverty or solving the problem of poverty, encouraging education, preventing behavioural disorders, applying employment measures and generally improving the quality of life of the Roma. Alongside with respecting, improving and implementing basic human rights and the rights of national minorities, one of the highest priorities is providing care to the Romani population in Croatia, primarily healthcare. Hygiene habits play a crucial role in the health of every individual. Considering the attitudes and the opinion of the Romani population on hygiene, some conclusions can be reached on the connections between hygiene habits and the health of the members of Romani families. Sadly, there are no studies on this topic in the relevant literature, which poses a significant problem in reaching general conclusions on the hygiene habits of the Roma both in Croatia and the world.

In Croatia, there are several Romani tribal groups, and in some areas they have been living for over 150 years: Lovari, Kalderash, Hajari, Sinti, Shiacs, Bayash or Koritari and Horahai, Kanjari, Arliye, Ludari. Some of them are Catholics, some Muslims and some Orthodox. Koritari speak the Roma dialect ljimba d' bjash, while Kalderash and Lovari speak Romani chib. The most populous Romani communities abide in Međimurje (30\% of the total Romani population), the city of Zagreb and the Osijek-Baranja County. Many live in and around the following urban centres: Rijeka, Pula, Bjelovar, Novska, Kutina, Sisak, Karlovac, Perušić, Đurđevac, Pitomača, Slavonski Brod, Beli Manastir, Darda, and Vukovar (4).

The care of the Roma in Croatia is under the jurisdiction of the Constitutional Law on National Minorities, with a special place devoted to the Framework Convention for the Protection of National Minorities and the European Charter on Regional and Minority Languages. Despite all of that, it should be emphasized that the political and social situations are not the most favourable for the Romani population. The most frequent ob- 
stacles are religious, ethnic and linguistic. In order to solve these problems, laws have been adopted for the purpose of ensuring a better integration of Roma into society. According to some statistical data, the highest concentration of Roma in Croatia is on the urban territories of Varaždin, Čakovec and Zageb, with a large part comprising the population of the Sisak-Moslavina County, especially its urban centre - Sisak. According to the abovementioned census, it can be stated that there is a statistical decrease in the number of members of all national minorities apart from Roma (5).

For the members of the Romani community to become as well integrated into society as possible, Croatia seeks to implement assimilation measures, with the importance of education being at the forefront. One such measure is the Equal Opportunities project - better integration of Romani children into the educational system of the Republic of Croatia. Taking into consideration the lower percentage of inclusion of Romani children into the school system, as well as a higher drop-out percentage, this project attempts to raise the awareness of the Romani community of the importance of education, but also raise the awareness of the education system itself, i.e. its (un)readiness to create and maintain a supportive environment in which cultural differences are appreciated, not just tolerated. At the same time, Romani children are encouraged to actively participate in the process. This is one objective where education is considered the most important factor on the path of the Roma's inclusion into society, according to Bakić-Tomić and Lapat (6). It should be noted that in Romani communities children are brought up collectively, which plays an immense role in an individual's upbringing. Bearing in mind the fact that in such instances children do not live under the supervision of immediate family members, it is only logical that they develop a different sense of belonging, physical and mental safety, as well as a different approach to moral values. As regards the insufficient inclusion of Romani children in education, particularly high-school education, it is not at all rare, albeit it is almost a rule that young Roma enter the world of adults and start their own families at a very early age. The lack of experience of adolescence is then reflected on parenthood, with Romani youth unready to raise their children. Apart from evident problems, such as immaturity, parenting is affected by other factors, such as the availability of basic services, undeveloped infrastructure, as well as various support structures. Poverty and unemployment further debilitate the growth and development of each individual, which is also the case in the Romani community, in which these problems are emphasized and crucial. Still, it should be pointed out that in spite of all that Romani communities almost as a rule consist of numerous families with a large number of children, unfailingly accompanied by a low level of education, family feuds, and inadequate healthcare (7). The medical condition of the Roma is significantly poorer than the average medical condition of the Croatian population as a whole. In most instances, they do not have health insurance and have no medical protection. The term medical condition implies vaccination, infant mortality, most common diseases, the number of labours in young Romani women, mostly aged 10 to 16 , the frequency and length of breast feeding, chronic diseases, accidents, risky behaviours, nutrition and hygiene habits (8). As regards the latter, a study was conducted for the purpose of better understanding the situation within the Romani community on the specific example of the Sisak-Moslavina County. Within the framework of the programme "Colourful inclusion of Sisak" under the patronage of the Town of Sisak and UNICEF, nurses from the Health Centre Sisak and Dr. Ivo Pedišić General Hospital in Sisak organize annual educational workshops for the Romani population. Education takes place in the facilities of the school in Hrastelnica and the community centre in Capraške poljane. Furthermore, Health Centre nurses also regularly visit Romani settlements Capraške poljane and Palanjak, where they measure blood pressure and the level of blood sugar, calculate the body mass index and implement individual and group training on the importance of hygiene, healthy nutrition and healthy living.

\section{Aim}

The research aims of this paper are as follows:

To examine the frequency of hospitalization as regards hygiene habits of Romani families in relation to the frequency of hospitalization of non-Romani families.

To examine the differences in living conditions between the Romani and non-Romani populations.

To examine the attitudes of the Romani population towards hygiene habits. 
To examine hygiene habits of the Romani in relation to non-Romani families.

To examine sources of information on the influence of hygiene habits on respiratory diseases.

The purpose of the study is to examine whether there are differences in hygiene habits between the Romani and non-Romani populations.

\section{Methods}

\section{Participants}

The study was conducted on a total of 100 participants, with 50 of them being members of the Romani families and 50 being members of non-Romani families hospitalized at the Paediatrics Ward of $\mathrm{Dr}$ Ivo Pedišić General Hospital in Sisak, Croatia, in 2018. The study was done by means of a specially designed questionnaire containing 36 questions. Prior to conducting the study, consent was obtained from the Ethical Committee of Dr Ivo Pedišić General Hospital, as well as the parents' written consent. The first part of the questionnaire encompasses the subjects' general information: data regarding age, gender, number of members of the household and the parents' level of education. The second part of the questionnaire examines the living conditions and hygienic conditions in the household. The third part of the questionnaire examines how often the parents take their children to the doctor's and in which circumstances. The fourth part of the questionnaire examines how often and for what diseases children have been hospitalized. The fifth part of the questionnaire examines the children's hygiene habits. The sixth part of the questionnaire examines the parents' education on the influence of hygiene habits on children's respiratory diseases.

\section{Statistics}

Categorical data is represented by the absolute and relative frequency. Categorical variable differences were tested by Fisher's exact test. The normality of numerical variable distribution was tested by the Shapiro-Wilk test, and due to discrepancies from the normal distribution numerical data is described with the median and the limits of the interquartile span, and non-parametric methods were used for testing differences. The differences of numerical variables between two independent groups were tested by the Mann-Whitney U test. All " $p$ " values are two-sided. The significance level was set to alpha $=0.05$. Statistical analysis was performed using MedCalc Statistical Software version 18.2.1 (MedCalc Software bvba, Ostend, Belgium; http://www.medcalc. org; 2018) and IBM SPSS Statistics 23 (IBM Corp. Released 2015. IBM SPSS Statistics for Windows, Version 23.0. Armonk, NY: IBM Corp.).

\section{Results}

The study was conducted on 100 subjects, of whom 50 (50\%) were from Romani families and 50 (50 $\%)$ from non-Romani families. There are somewhat more women, 87 (87\%). In Romani families 30 (30 $\%)$ subjects did not complete primary school, with 9/30 having finished only the first four grades of primary school and 5/30 subjects having finished higher grades of primary school. To a statistically significant extent, more subjects from Romani families finished only primary school while subjects from non-Romani families graduated from high-schools, polytechnics or universities (Fischer's exact test, $p<0.001$ ) (Table1).

The subjects from Romani families are significantly younger, the median age being 25 (interquartile span from 21 to 30) in the span from 15 to 52 (Mann Whitney $U$ test, $p<0.001$ ). According to the number of household members in a single household, there are significantly more members in Romani families (Mann Whitney $U$ test, $p<0.001$ ), median 7 (interquartile span from 5 to 8 members) in the span from 2 to 12 members (Table 2 ). 


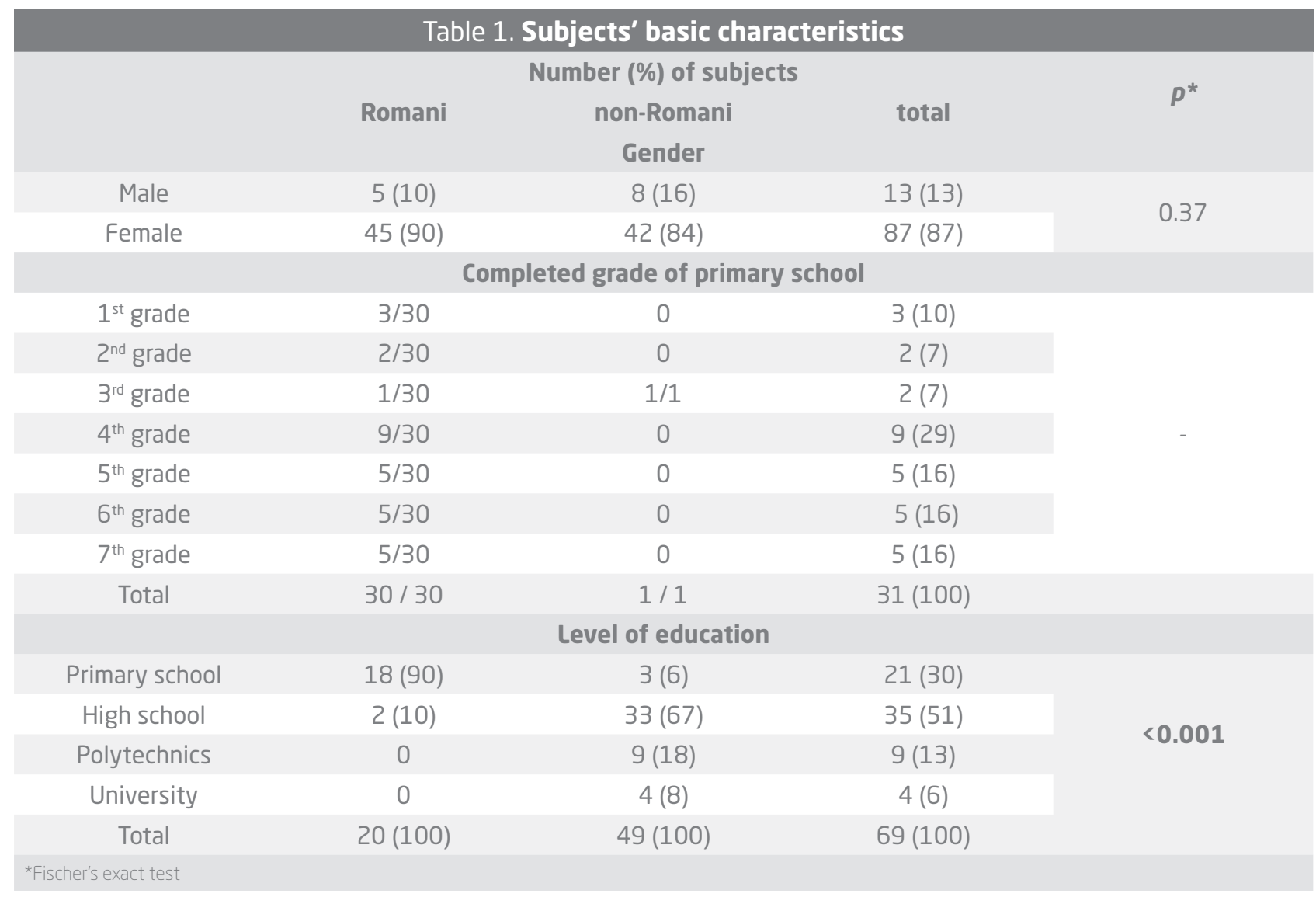

\section{Importance of hygiene}

Opinions and attitudes on hygiene are assessed via four domains: living conditions, care for health, hygiene habits, and being informed on the influence of hygiene habits on children's respiratory diseases.

\section{Frequency of children's hospitalizations}

38 (38\%) children were hospitalized once in 6 months due to respiratory problems, and 26 (26\%) children several times in 6 months, with significantly more cases (21, i.e. $43 \%$ ) occurring among Rom- ani families (Fischer's exact test, $p<0.001$ ). Due to other conditions, children were hospitalized once in 6 months in 46 (46\%) cases an only in 5 (5\%) instances several times in 6 months, with significantly more cases occurring among non-Romani families (Fischer's exact test, $p=0.002$ ).

\section{Living conditions}

$96(96 \%)$ of the subjects live in brick houses, with 99 (99\%) having electricity. 92 (92\%) use a furnace for heating. Children have their own room in 70 (70 $\%)$ cases and 95 (95\%) subjects regularly clean and

\section{Table 2. Subjects' age and number of household members}

\begin{tabular}{|c|c|c|c|c|}
\hline & \multicolumn{3}{|c|}{ Median (interquartile span) } & \multirow[b]{2}{*}{$p^{*}$} \\
\hline & Romani & non-Romani & total & \\
\hline Subjects' age & $25(21-30)$ & $33(28-40)$ & $29(23-35)$ & $<0.001$ \\
\hline Number of household members & $7(5-8)$ & $4(3-5)$ & $5(4-7)$ & $<0.001$ \\
\hline
\end{tabular}




\section{Table 3. Frequency of hospitalization due to respiratory problems in relation to groups}

\begin{tabular}{|c|c|c|c|c|}
\hline & \multicolumn{3}{|c|}{ Number $(\%)$ of subjects } & \multirow{3}{*}{$p^{*}$} \\
\hline & Romani & non-Romani & Total & \\
\hline \multicolumn{4}{|c|}{ Child was hospitalized due to respiratory problems } & \\
\hline Never & 7 (14) & 28 (56) & 35 (35) & \\
\hline Once in 6 months & $21(43)$ & $17(34)$ & $38(38)$ & $<0.001$ \\
\hline Several times in 6 months & $21(43)$ & $5(10)$ & $26(26)$ & \\
\hline \multicolumn{5}{|c|}{ Child was hospitalized due to other diseases } \\
\hline Never & $32(65)$ & $16(32)$ & $48(48)$ & \multirow{3}{*}{0.002} \\
\hline Once in 6 months & $15(31)$ & $31(62)$ & $46(46)$ & \\
\hline Several times in 6 months & $2(4)$ & $3(6)$ & $5(5)$ & \\
\hline Total & $49(100)$ & $50(100)$ & 99 (100) & \\
\hline
\end{tabular}

\section{Table 4. Living conditions according to groups}

\begin{tabular}{|c|c|c|c|c|}
\hline & \multicolumn{3}{|c|}{ Number $(\%)$ of subjects } & \multirow{2}{*}{$p^{*}$} \\
\hline & Romani & non-Romani & Total & \\
\hline Live in a brick house & $46(92)$ & $50(100)$ & $96(96)$ & 0.12 \\
\hline Have an indoor toilet & $27(54)$ & $50(100)$ & $77(77)$ & $<0.001$ \\
\hline Have electricity in the house & $49(98)$ & $50(100)$ & 99 (99) & $>0.99$ \\
\hline Have city plumbing in the house & $29(59)$ & $47(94)$ & $76(76)$ & $<0.001$ \\
\hline Furnace heating (wood, gas) & $45(98)$ & $47(94)$ & $92(92)$ & 0.62 \\
\hline Children have their own room & $32(64)$ & $38(78)$ & $70(70)$ & 0.19 \\
\hline The house is cleaned regularly (vacuuming, washing) & $45(92)$ & $50(100)$ & $95(95)$ & 0.06 \\
\hline The house has a bathroom (shower, bathtub) & $28(56)$ & $50(100)$ & $78(78)$ & $<0.001$ \\
\hline The house is aired regularly & $45(90)$ & $50(100)$ & $95(95)$ & 0.06 \\
\hline Children co-sleep with their parents & 19 (39) & $12(24)$ & 31 (31) & 0.13 \\
\hline
\end{tabular}

air their home. In 31 (31\%) cases children co-sleep with their parents, without a statistically relevant difference in terms of Romani and non-Romani families. Subjects from Romani families statistically significantly lack a toilet, city plumbing and a bathroom in the house (Fischer's exact test, $p<0.001$ ) (Table 4).

In the group of Romani families there are no statistically significant differences in living conditions in relation to the number of household members, while among non-Romani families there are significantly fewer of those who live in communal households with 5 to 7 household members who have indoor plumbing. Fischer's exact test, $p=0.04$ ) (Table 5). These questions are dichotomous, so the first number relates to those in which the condition is met, i.e. who answered the question in the affirmative.
In Romani families, significantly fewer children are hospitalized, once in 6 months in subjects who have indoor plumbing (Fischer's exact test, $p=0.03$ ). Children who have their own room are significantly less frequently hospitalized due to respiratory diseases (never or once in 6 months) (Fischer's exact test, $p=0.04$ ) (Table 6).

\section{Care for children's health}

57 (58\%) subjects often take their children to the doctor's when the child is ill and 27 (27\%) subjects sometimes don't trust the doctor and only go to the doctor's when the child is very ill, with no significant difference in terms of Romani and non-Romani families. Children from Romani families are significantly 


\section{Table 5. Living conditions according to the number of household members}

\begin{tabular}{|c|c|c|c|c|}
\hline & \multicolumn{3}{|c|}{$\begin{array}{l}\text { Number of subjects according to } \\
\text { number of household members }\end{array}$} & \multirow[t]{2}{*}{$p^{\star}$} \\
\hline & Up to 4 & $5-7$ & 8 and more & \\
\hline \multicolumn{5}{|c|}{ ROMANI FAMILIES } \\
\hline Live in a brick house & 8/11 & $24 / 25$ & $14 / 14$ & 0.05 \\
\hline Have an indoor toilet & $7 / 11$ & $14 / 25$ & $6 / 14$ & 0.53 \\
\hline Have electricity in the house & $11 / 11$ & $24 / 25$ & $14 / 14$ & $>0.99$ \\
\hline Have city plumbing in the house & $8 / 11$ & $16 / 25$ & $5 / 13$ & 0.19 \\
\hline Furnace heating (wood, gas) & $9 / 10$ & $24 / 24$ & $12 / 12$ & 0.22 \\
\hline Children have their own room & $10 / 11$ & $15 / 25$ & $7 / 14$ & 0.09 \\
\hline The house is cleaned regularly (vacuuming, washing) & $8 / 10$ & $24 / 25$ & $13 / 14$ & 0.28 \\
\hline The house has a bathroom (shower, bathtub) & $3 / 11$ & $11 / 25$ & $6 / 14$ & 0.35 \\
\hline The house is aired regularly & $10 / 11$ & $22 / 25$ & $13 / 14$ & $>0.99$ \\
\hline Children co-sleep with their parents & $4 / 11$ & $9 / 25$ & $6 / 13$ & 0.86 \\
\hline \multicolumn{5}{|c|}{ NON- ROMANI FAMILIES } \\
\hline Live in a brick house & 33/33 & $15 / 15$ & $2 / 2$ & - \\
\hline Have an indoor toilet & 33/33 & $15 / 15$ & $2 / 2$ & - \\
\hline Have electricity in the house & 33/33 & $15 / 15$ & $2 / 2$ & - \\
\hline Have city plumbing in the house & 33/33 & $12 / 15$ & $2 / 2$ & 0.04 \\
\hline Furnace heating (wood, gas) & 31/33 & $14 / 15$ & $2 / 2$ & $>0.99$ \\
\hline Children have their own room & 24/33 & $12 / 14$ & $2 / 2$ & 0.68 \\
\hline The house is cleaned regularly (vacuuming, washing) & 33/33 & $15 / 15$ & $2 / 2$ & - \\
\hline The house has a bathroom (shower, bathtub) & 33/33 & $15 / 15$ & $2 / 2$ & - \\
\hline The house is aired regularly & 33/33 & $15 / 15$ & $2 / 2$ & - \\
\hline Children co-sleep with their parents & $9 / 33$ & $3 / 15$ & $0 / 2$ & 0.84 \\
\hline
\end{tabular}

more often taken to the hospital when they are injured or for a regular check-up, and significantly less frequently when all they need is medical advice (Fischer's exact test, $p<0.001$ ) in relation to children from non-Romani families (Table 7). There are no significant differences in care for children's health in relation to the number of household members (Table 11). In Romani families, a significant number of children who were often taken to the doctor's when they were injured (Fischer's exact test, $p<0.001$ ), for regular appointments (Fischer's exact test, $p=0.007$ ), or simply for a piece of advice from the doctor (Fischer's exact test, $p=0.001$ ) were not hospitalized due to respiratory problems when compared to children who were never taken to the doctor's or only occasionally (Table 8).

\section{Hygiene habits}

$98(98 \%)$ subjects state that they remind the children daily to wash their hands before a meal, and 95 (95\%) that every child has his or her own toothbrush. Children change their underwear every day, as stated by 92 (92\%) subjects, with no significant difference in terms of whether the family is Romani or not. In non-Romani families children take a shower every day significantly more (Fischer's exact test, $p=0.002$ ), and it is stated that it is not enough to change a towel once a week significantly more (Fischer's exact test, $p<0.001)$, as well as that children sleep in their pyjamas (Fischer's exact test, $p<0.001$ ).

In the group of non-Romani families, children brush their teeth in the morning and in the evening significantly more, while in Romani families 21 (43\%) sub- 
Table 6. Living conditions according to the frequency of hospitalization due to respiratory diseases

\begin{tabular}{|c|c|c|c|c|}
\hline & \multicolumn{3}{|c|}{$\begin{array}{l}\text { Number }(\%) \text { of subjects according to the } \\
\text { number of hospitalization instances }\end{array}$} & \multirow{2}{*}{$p^{*}$} \\
\hline & Never & $\begin{array}{l}\text { Once in } 6 \\
\text { months }\end{array}$ & $\begin{array}{l}\text { Several times } \\
\text { in } 6 \text { months }\end{array}$ & \\
\hline \multicolumn{5}{|c|}{ ROMANI FAMILIES } \\
\hline Live in a brick house & $5 / 7$ & $21 / 21$ & $19 / 21$ & 0.05 \\
\hline Have an indoor toilet & $4 / 7$ & $11 / 21$ & $11 / 21$ & $>0.99$ \\
\hline Have electricity in the house & $7 / 7$ & $21 / 21$ & $20 / 21$ & $>0.99$ \\
\hline Have city plumbing in the house & $7 / 7$ & $9 / 21$ & $12 / 21$ & 0.03 \\
\hline Furnace heating (wood, gas) & $7 / 7$ & $19 / 21$ & $18 / 21$ & $>0.99$ \\
\hline Children have their own room & $7 / 7$ & $10 / 21$ & $14 / 21$ & 0.04 \\
\hline The house is cleaned regularly (vacuuming, washing) & $7 / 7$ & $17 / 21$ & $20 / 21$ & 0.73 \\
\hline The house has a bathroom (shower, bathtub) & $6 / 7$ & $10 / 21$ & $11 / 21$ & 0.24 \\
\hline The house is aired regularly & $7 / 7$ & $18 / 21$ & $19 / 21$ & 0.84 \\
\hline Children co-sleep with their parents & $2 / 7$ & $8 / 21$ & $9 / 21$ & 0.85 \\
\hline \multicolumn{5}{|c|}{ NON- ROMANI FAMILIES } \\
\hline Live in a brick house & $28 / 28$ & $17 / 17$ & $5 / 5$ & - \\
\hline Have an indoor toilet & $28 / 28$ & $17 / 17$ & $5 / 5$ & - \\
\hline Have electricity in the house & $28 / 28$ & $17 / 17$ & $5 / 5$ & - \\
\hline Have city plumbing in the house & $25 / 28$ & $17 / 17$ & $5 / 5$ & 0.48 \\
\hline Furnace heating (wood, gas) & $26 / 28$ & $16 / 17$ & $5 / 5$ & $>0.99$ \\
\hline Children have their own room & $20 / 27$ & $14 / 17$ & $4 / 5$ & 0.88 \\
\hline The house is cleaned regularly (vacuuming, washing) & $28 / 28$ & $17 / 17$ & $5 / 5$ & - \\
\hline The house has a bathroom (shower, bathtub) & $28 / 28$ & $17 / 17$ & $5 / 5$ & - \\
\hline The house is aired regularly & $28 / 28$ & $17 / 17$ & $5 / 5$ & - \\
\hline Children co-sleep with their parents & $8 / 28$ & $3 / 17$ & $1 / 5$ & 0.79 \\
\hline
\end{tabular}

jects state that they brush their teeth in the morning and in the evening, with $20(41 \%)$ answering that they do not know (Fischer's exact test, $p<0.001$ ). A toothbrush is not used for more than three months by significantly more subjects from non-Romani families, 43 (83\%) of them, while 16 (32\%) subjects from Romani families answered that they do not know how long the children use their toothbrushes (Fischer's exact test, $p<0.001$ ) (Table 10).

There are no significant differences in hygiene habits according to the number of household members (Table 10) and frequency of hospitalization due to respiratory problems (Table 11 ).

\section{Information on the influence of hygiene habits on respiratory diseases}

$86(86 \%)$ subjects are informed on the influence of hygiene habits on respiratory diseases, significantly more from non-Romani families (Fischer's exact test, $p=0.04)$, with significantly more (28, i.e. $56 \%)$ stating that they had been informed by a doctor (Fischer's exact test, $p=0.005) .59(59 \%)$ subjects had been informed by a nurse, 23 (23\%) by a friend and 54 (54\%) subjects by family, with no significant differences in terms of whether the family is Romani or not (Table 13). 


\section{Table 7. Care for children's health in relation to groups}

\begin{tabular}{|c|c|c|c|c|}
\hline \multicolumn{4}{|c|}{ Number $(\%)$ of subjects } & \multirow{2}{*}{$p^{*}$} \\
\hline & Romani & non-Romani & Total & \\
\hline \multicolumn{5}{|c|}{ Take the child to the doctor's when he or she is ill } \\
\hline Never & $2(4)$ & $1(2)$ & $3(3)$ & \multirow{3}{*}{0.55} \\
\hline Sometimes & $17(35)$ & $22(44)$ & 39 (39) & \\
\hline Often & $30(61)$ & $27(54)$ & $57(58)$ & \\
\hline \multicolumn{5}{|c|}{ Take the child to the doctor's when he or she is injured } \\
\hline Never & $2(4)$ & $4(8)$ & $6(6)$ & \multirow{3}{*}{$<0.001$} \\
\hline Sometimes & $39(80)$ & $22(44)$ & $61(62)$ & \\
\hline Often & $8(16)$ & $24(48)$ & $32(32)$ & \\
\hline \multicolumn{5}{|c|}{ Take the child to the doctor's for a regular check-up } \\
\hline Never & $1(2)$ & $1(2)$ & $2(2)$ & \multirow{3}{*}{$<0.001$} \\
\hline Sometimes & $25(51)$ & $3(6)$ & $28(28)$ & \\
\hline Often & $23(47)$ & $46(92)$ & $69(70)$ & \\
\hline \multicolumn{5}{|c|}{ Go to the doctor's when they need medical advice } \\
\hline Never & $37(76)$ & $7(14)$ & $44(44)$ & \multirow{3}{*}{$<0.001$} \\
\hline Sometimes & $8(16)$ & $28(56)$ & $36(36)$ & \\
\hline Often & $4(8)$ & $15(30)$ & 19 (19) & \\
\hline \multicolumn{5}{|c|}{ Do not trust the doctor and only go to the doctor's when the child is very ill } \\
\hline Never & $30(61)$ & $36(72)$ & $66(67)$ & \multirow{3}{*}{0.49} \\
\hline Sometimes & $16(33)$ & $11(22)$ & $27(27)$ & \\
\hline Often & $3(6)$ & $3(6)$ & $6(6)$ & \\
\hline Total & 49 (100) & $50(100)$ & 99 (100) & \\
\hline
\end{tabular}

\section{Discussion}

The results of the questionnaire show that due to respiratory problems $38 \%$ of children were hospitalized once in 6 months, and $26 \%$ children were hospitalized several times in six months, significantly more (43\%) from Romani families. Due to other diseases, $46 \%$ of cases were hospitalized once in 6 months, and only $5 \%$ cases were hospitalized several times in six months, significantly more among non-Romani families. As far as living conditions are concerned, the results clearly demonstrate that indoor toilets, indoor plumbing and bathrooms are significantly lacking for subjects from Romani families. In Romani families, significantly fewer children were hospitalized (once in 6 months) among subjects who have indoor city plumbing. Children who have their own room are significantly less frequently hospitalized due to respiratory disease (never or once in 6 months). Children from Romani families are significantly more often taken to the doctor's when they are injured or for a regular check-up, and significantly less frequently for medical advice.

In non-Romani families significantly more children take a shower every day, each has his or her own towel, the participants state significantly more that it is not enough to change a towel once a week, and children sleep in their pyjamas more often. To a significant extent, children brush their teeth in the morning and in the evening in the group of non-Romani families, while among Romani families 21 (43\%) subjects claim that the children brush their teeth in the morning and in the evening, while 20 (41\%) answered that they do not know. $86 \%$ of subjects are 
Table 8. Care for children's health in relation to the number of household members Number (\%) of subjects according to the number of household members

$\begin{array}{lcc}\text { Up to } 4-7 & 8 \text { and more }\end{array}$

p*

Take the child to the doctor's when he or she is ill

$\begin{array}{cccc}\text { Never } & 1(9) & 1(4) & 0 \\ \text { Sometimes } & 3(27) & 9(38) & 5(36) \\ \text { Often } & 7(64) & 14(58) & 9(64)\end{array}$

Take the child to the doctor's when he or she is injured

$\begin{array}{cccc}\text { Never } & 0 & 2(8) & 0 \\ \text { Sometimes } & 8(73) & 19(79) & 12(86) \\ \text { Often } & 3(27) & 3(13) & 2(14)\end{array}$

Take the child to the doctor's for a regular check-up

$\begin{array}{cccc}\text { Never } & 0 & 1(4) & 0 \\ \text { Sometimes } & 3(27) & 14(58) & 8(57) \\ \text { Often } & 8(73) & 9(38) & 6(43) \\ & \text { Go to the doctor's when they need medical advice } \\ \text { Never } & 6(55) & 19(79) & 12(86) \\ \text { Sometimes } & 2(18) & 4(17) & 2(14) \\ \text { Often } & 3(27) & 1(4) & 0\end{array}$

Do not trust the doctor and only go to the doctor's when the child is very ill

$\begin{array}{cccc}\text { Never } & 7(64) & 15(63) & 8(57) \\ \text { Sometimes } & 3(27) & 8(33) & 5(36) \\ \text { Often } & 1(9) & 1(4) & 1(7) \\ \text { Total } & 11(100) & 24(100) & 14(100)\end{array}$

\section{NON-ROMANI FAMILIES}

Take the child to the doctor's when he or she is ill

$\begin{array}{cccc}\text { Never } & 0 & 1(7) & 0 \\ \text { Sometimes } & 14(42) & 8(53) & 0 \\ \text { Often } & 19(58) & 6(40) & 2(100)\end{array}$

Take the child to the doctor's when he or she is injured

$\begin{array}{cccc}\text { Never } & 3(9) & 1(7) & 0 \\ \text { Sometimes } & 14(42) & 8(53) & 0 \\ \text { Often } & 16(48) & 6(40) & 2(100)\end{array}$

Take the child to the doctor's for a regular check-up

$\begin{array}{cccc}\text { Never } & 0 & 1(7) & 0 \\ \text { Sometimes } & 3(9) & 0 & 0 \\ \text { Often } & 30(91) & 14(93) & 2(100) \\ & \text { Go to the doctor's } & \text { when they need medical advice } \\ \text { Never } & 5(15) & 2(13) & 0 \\ \text { Sometimes } & 19(58) & 9(60) & 0 \\ \text { Often } & 9(27) & 4(27) & 2(100)\end{array}$

Do not trust the doctor and only go to the doctor's when the child is very ill

$\begin{array}{cccc}\text { Never } & 22(67) & 13(87) & 1(50) \\ \text { Sometimes } & 9(27) & 2(13) & 0 \\ \text { Often } & 2(6) & 0 & 1(50) \\ \text { Total } & 33(100) & 15(100) & 2(100)\end{array}$




\section{Table 9. Care for children's health in relation to the frequency of hospitalization due to respiratory problems}

Number (\%) of subjects in relation to the frequency of respiratory problems

$\begin{array}{cccc} & \text { Never } & \begin{array}{c}\text { Once in } \mathbf{6} \text { months } \\ \text { ROMANI FAMILIES }\end{array} & \begin{array}{c}\text { Several times } \\ \text { months }\end{array} \\ \text { Never } & 1(14) & 0 & 1(5) \\ \text { Sometimes } & 0 & 10(48) & 7(33) \\ \text { Often } & 6(86) & 11(52) & 13(62) \\ \text { Never } & \text { Take the child to the doctor's when he or she is injured } \\ \text { Sometimes } & 1(14) & 1(5) & 0 \\ \text { Often } & 1(14) & 20(95) & 18(86) \\ & 5(71) & 0 & 3(14) \\ \text { Never } & \text { Take the child to the doctor's for a regular check-up } \\ \text { Sometimes } & 1(14) & 0 & 0 \\ \text { Often } & 0 & 14(67) & 11(52) \\ & 6(86) & 7(33) & 10(48) \\ \text { Never } & \text { Go to the doctor's when they need medical advice } \\ \text { Sometimes } & 2(29) & 17(81) & 18(86) \\ \text { Often } & 3(43) & 4(19) & 1(5) \\ & 2(29) & 0 & 2(10)\end{array}$

p*

Take the child to the doctor's when he or she is injured

Do not trust the doctor and only go to the doctor's when the child is very ill

$\begin{array}{cccc}\text { Never } & 3(43) & 15(71) & 12(57) \\ \text { Sometimes } & 2(29) & 6(29) & 8(38) \\ \text { Often } & 2(29) & 0 & 1(5) \\ \text { Total } & 7(100) & 21(100) & 21(100)\end{array}$

NON-ROMANI FAMILIES

Take the child to the doctor's when he or she is ill

$\begin{array}{cccc}\text { Never } & 1(4) & 0 & 0 \\ \text { Sometimes } & 16(57) & 4(24) & 2(40) \\ \text { Often } & 11(39) & 13(76) & 3(60)\end{array}$

Take the child to the doctor's when he or she is injured

$\begin{array}{cccc}\text { Never } & 4(14) & 0 & 0 \\ \text { Sometimes } & 11(39) & 9(53) & 2(40) \\ \text { Often } & 13(46) & 8(47) & 3(60)\end{array}$

Take the child to the doctor's for a regular check-up

$\begin{array}{cccc}\text { Never } & 1(4) & 0 & 0 \\ \text { Sometimes } & 2(7) & 1(6) & 0 \\ \text { Often } & 25(89) & 16(94) & 5(100) \\ & \text { Go to the doctor's } & \text { when they need medical advice } \\ \text { Never } & 4(14) & 2(12) & 1(20) \\ \text { Sometimes } & 16(57) & 9(53) & 3(60) \\ \text { Often } & 8(29) & 6(35) & 1(20)\end{array}$

Do not trust the doctor and only go to the doctor's when the child is very ill

$\begin{array}{ccccc}\text { Never } & 18(64) & 14(82) & 4(80) & 0.75 \\ \text { Sometimes } & 8(29) & 2(12) & 1(20) & 0 \\ \text { Often } & 2(7) & 1(6) & 5(100)\end{array}$




\section{Table 10. Hygiene habits in relation to groups}

\begin{tabular}{|c|c|c|c|c|}
\hline & \multicolumn{3}{|c|}{ Number $(\%)$ of subjects } & \multirow{2}{*}{$\mathbf{p}^{*}$} \\
\hline & Romani & Non-Romani & Total & \\
\hline Children are reminded daily to wash their hands before a meal & 49 (98) & $49(98)$ & $98(98)$ & $>0.99$ \\
\hline Every child has his or her own toothbrush & $45(90)$ & $50(100)$ & $95(95)$ & 0.06 \\
\hline Children take a shower every day & $29(58)$ & $42(84)$ & $71(71)$ & 0.008 \\
\hline Every person in the house has his or her own towel & $32(64)$ & $46(92)$ & $78(78)$ & 0.002 \\
\hline It is not enough to change a towel once a week & $21(42)$ & $45(90)$ & $66(66)$ & $<0.001$ \\
\hline Children are responsible for their own cleanliness & $10(20)$ & $21(42)$ & $31(31)$ & 0.04 \\
\hline Children sleep in their pyjamas & $32(64)$ & $47(94)$ & 79 (79) & $<0.001$ \\
\hline Children brush their teeth in the morning and in the evening & $21(43)$ & $44(88)$ & $65(65)$ & $<0.001$ \\
\hline A toothbrush is not used for more than three months & $17(34)$ & $43(86)$ & $60(60)$ & $<0.001$ \\
\hline $\begin{array}{c}\text { Children change their underwear every day (underpants, } \\
\text { undershirts) }\end{array}$ & $44(88)$ & $48(96)$ & $92(92)$ & 0.06 \\
\hline
\end{tabular}

\section{Table 11. Hygiene habits in relation to number of household members}

\section{Number/total subjects according to the} number of household members

\section{Up to $4 \quad 5$ - $7 \quad 8$ and more}

ROMANI FAMILIES

$\begin{array}{ccccc}\text { Children are reminded daily to wash their hands before a meal } & 11 / 11 & 24 / 25 & 14 / 14 & >0.99 \\ \text { Every child has his or her own toothbrush } & 10 / 11 & 21 / 25 & 14 / 14 & 0.64 \\ \text { Children take a shower every day } & 8 / 11 & 15 / 25 & 6 / 14 & 0.47 \\ \text { Every person in the house has his or her own towel } & 9 / 11 & 16 / 25 & 7 / 14 & 0.53 \\ \text { It is not enough to change a towel once a week } & 6 / 11 & 9 / 25 & 6 / 14 & 0.61 \\ \text { Children are responsible for their own cleanliness } & 5 / 11 & 7 / 25 & 1 / 14 & 0.24 \\ \text { Children sleep in their pyjamas } & 8 / 11 & 17 / 25 & 7 / 14 & 0.50\end{array}$

Children sleep in their pyjamas

Children brush their teeth in the morning and in the evening

Yes

No

I do not know

$7 / 11$

0

$11 / 24$

$5 / 24$

$8 / 24$ Yes

No

I do not know

Children change their underwear every day (underpants, undershirts)

\section{NON-ROMANI FAMILIES}

Children are reminded daily to wash their hands before a meal

Every child has his or her own toothbrush

Children take a shower every day

Every person in the house has his or her own towel

It is not enough to change a towel once a week

Children are responsible for their own cleanliness

Children sleep in their pyjamas

Children brush their teeth in the morning and in the evening

A toothbrush is not used for more than three months

Children change their underwear every day (underpants, undershirts)

*Fischer's exact test
$33 / 33$

$33 / 33$

$27 / 33$

$31 / 33$

$30 / 33$

$14 / 33$

$31 / 33$

28/33

29/33

$31 / 33$

\begin{abstract}
2/11
\end{abstract}
$3 / 11$

$11 / 25$

$9 / 25$

$5 / 25$

21/25

$14 / 15$

$15 / 15$

13/15

$14 / 15$

$14 / 15$

$6 / 15$

$14 / 15$

14/15

$13 / 33$

$15 / 15$ p*

$3 / 14$

$3 / 14$

0.17

$8 / 14$

$4 / 14$

$2 / 14$

$8 / 14$

$12 / 14$

0.79

\subsection{9}

$\begin{array}{cc}2 / 2 & 0.34 \\ 2 / 2 & - \\ 2 / 2 & >0.99 \\ 1 / 2 & 0.23 \\ 1 / 2 & 0.26 \\ 1 / 2 & >0.99 \\ 2 / 2 & >0.99 \\ 2 / 2 & 0.73 \\ 1 / 2 & 0.40 \\ 2 / 2 & >0.99\end{array}$




\title{
Table 12. Hygiene habits in relation to the number of hospitalizations due to respiratory problems
}

\author{
Number/total subjects according to \\ the number of hospitalizations due to \\ respiratory diseases
}

\begin{tabular}{|c|c|c|c|c|}
\hline \multicolumn{5}{|l|}{ 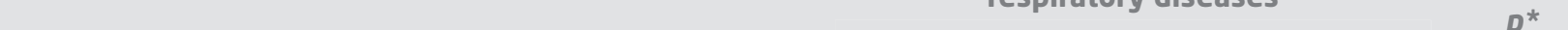 } \\
\hline ( & Never & $\begin{array}{c}\text { Once in } 6 \\
\text { months }\end{array}$ & $\begin{array}{l}\text { Several } \\
\text { times in } 6 \\
\text { months }\end{array}$ & \\
\hline \multicolumn{5}{|c|}{ ROMANI FAMILIES } \\
\hline Children are reminded daily to wash their hands before a meal & $7 / 7$ & $21 / 21$ & $20 / 21$ & $>0.99$ \\
\hline Every child has his or her own toothbrush & $7 / 7$ & 21/21 & $16 / 21$ & 0.16 \\
\hline Children take a shower every day & $6 / 7$ & $10 / 21$ & $12 / 21$ & 0.28 \\
\hline Every person in the house has his or her own towel & $6 / 7$ & $11 / 21$ & $14 / 21$ & 0.10 \\
\hline It is not enough to change a towel once a week & $5 / 7$ & $10 / 21$ & $6 / 21$ & 0.11 \\
\hline Children are responsible for their own cleanliness & $3 / 7$ & $2 / 21$ & $4 / 21$ & 0.16 \\
\hline Children sleep in their pyjamas & $6 / 7$ & $12 / 21$ & $13 / 21$ & 0.62 \\
\hline
\end{tabular}

Children brush their teeth in the morning and in the evening

\begin{tabular}{|c|c|c|c|c|}
\hline \\
\hline Yes & $5 / 7$ & $9 / 21$ & $6 / 20$ & \multirow{3}{*}{0.43} \\
\hline No & $1 / 7$ & $3 / 21$ & $4 / 20$ & \\
\hline I do not know & $1 / 7$ & $9 / 21$ & $10 / 20$ & \\
\hline \multicolumn{5}{|c|}{ A toothbrush is not used for more than three months } \\
\hline Yes & 0 & $7 / 21$ & $9 / 21$ & \multirow{3}{*}{0.06} \\
\hline No & $6 / 7$ & $6 / 21$ & $5 / 21$ & \\
\hline I do not know & $1 / 7$ & $8 / 21$ & $7 / 21$ & \\
\hline $\begin{array}{c}\text { Children change their underwear every day (underpants, } \\
\text { undershirts) }\end{array}$ & $7 / 7$ & $17 / 21$ & $19 / 21$ & 0.73 \\
\hline \multicolumn{5}{|c|}{ NON-ROMANI FAMILIES } \\
\hline Children are reminded daily to wash their hands before a meal & $28 / 28$ & $16 / 17$ & $5 / 5$ & 0.44 \\
\hline Every child has his or her own toothbrush & $28 / 28$ & $17 / 17$ & $5 / 5$ & - \\
\hline Children take a shower every day & $21 / 28$ & $16 / 17$ & $5 / 5$ & 0.17 \\
\hline Every person in the house has his or her own towel & $24 / 25$ & $17 / 17$ & $5 / 5$ & 0.40 \\
\hline It is not enough to change a towel once a week & $26 / 28$ & $16 / 17$ & $3 / 5$ & 0.11 \\
\hline Children are responsible for their own cleanliness & $11 / 28$ & $8 / 17$ & $2 / 5$ & 0.95 \\
\hline Children sleep in their pyjamas & $25 / 28$ & $17 / 17$ & $5 / 5$ & 0.48 \\
\hline Children brush their teeth in the morning and in the evening & 23/28 & $16 / 17$ & $5 / 5$ & 0.44 \\
\hline A toothbrush is not used for more than three months & $24 / 28$ & $15 / 17$ & $4 / 5$ & $>0.99$ \\
\hline $\begin{array}{l}\text { Children change their underwear every day (underpants, } \\
\text { undershirts) }\end{array}$ & $26 / 28$ & $17 / 17$ & $5 / 5$ & 0.61 \\
\hline Fischer's exact test & & & & \\
\hline
\end{tabular}

acquainted with the influence of hygiene habits on respiratory diseases, significantly more so from nonRomani families, with a relevant $56 \%$ stating that information was obtained from a doctor. It is possible that poorer hygiene habits in Romani families are affected by poor conditions, rather than incom- petence. Not being aware of the personal hygiene habits of their own children within Romani families speaks of the problem of poor communication among family members, as well as traces of family neglect. According to a study by Belak, Madarasova Geckova, van Dijk, and Reijneveld, the Romani community in 


\begin{tabular}{|c|c|c|c|c|}
\hline \multicolumn{4}{|c|}{ Number (\%) of subjects } & \multirow{2}{*}{$p^{*}$} \\
\hline & Romani & non-Romani & Total & \\
\hline \multicolumn{5}{|c|}{ Are informed on the influence } \\
\hline Yes & $39(78)$ & $47(94)$ & $86(86)$ & \multirow{3}{*}{0.04} \\
\hline No & $10(20)$ & $3(6)$ & $13(13)$ & \\
\hline I do not know & $1(2)$ & 0 & $1(1)$ & \\
\hline \multicolumn{5}{|c|}{ Were informed by a doctor } \\
\hline Yes & $13(26)$ & $28(56)$ & $41(41)$ & \multirow{3}{*}{0.005} \\
\hline No & $33(66)$ & $21(42)$ & $54(54)$ & \\
\hline I do not know & $4(8)$ & $1(2)$ & $5(5)$ & \\
\hline \multicolumn{5}{|c|}{ Were informed by a nurse } \\
\hline Yes & $26(52)$ & $33(66)$ & $59(59)$ & \multirow{3}{*}{0.41} \\
\hline No & $22(44)$ & $16(32)$ & $38(38)$ & \\
\hline I do not know & $2(4)$ & $1(2)$ & $3(3)$ & \\
\hline \multicolumn{5}{|c|}{ Were informed by a friend } \\
\hline Yes & $7(14)$ & $16(32)$ & $23(23)$ & \multirow{3}{*}{0.05} \\
\hline No & $38(76)$ & $33(66)$ & $71(71)$ & \\
\hline I do not know & $5(10)$ & $1(2)$ & $6(6)$ & \\
\hline \multicolumn{5}{|c|}{ Were informed by their family } \\
\hline Yes & $26(52)$ & $28(56)$ & $54(54)$ & \multirow{3}{*}{0.88} \\
\hline No & $22(44)$ & $21(42)$ & $43(43)$ & \\
\hline I do not know & $2(4)$ & $1(2)$ & $3(3)$ & \\
\hline Total & $50(100)$ & $50(100)$ & $100(100)$ & \\
\hline
\end{tabular}

Slovakia has similar problems with living conditions which greatly affect their medical state, as well as other problems in terms of using medical services. Only a few affluent members of the Romani community used medical services every time the need arose, while others used them only in instances of utmost necessity. Those who were not able to use medical services at their own expense would unjustifiably use the services of emergency medical assistance or some method of self-treatment (9). The results of the study demonstrated that information on the importance of education is not obtained by Romani families from their family members, not even noticeably within the educational system, but instead from healthcare workers with whom they have had direct contact when visiting a hospital ward or during lengthy hospitalization. The situation in Romani families included in this study is comparable to cases of the Romani population on the territory of the entire country and wider, which is why the results obtained from the questionnaire and the conclusions derived from them can be used for the purpose of educating Romani families on the importance and rules of hygiene habits. In the case of the latter, progress has been achieved in the case of the Roma in the Sisak-Moslavina County, more specifically the urban centres of Sisak, Kutina and Popovača. A higher education level of the Roma is one of the major concerns of the Association for the development and improvement of the lives of the Roma, the goal of which is to promote the importance of education and employment of the members of the Romani national minority, and whose activities focus on overcoming basic obstacles when employing the Roma, low education levels among the Roma, and the general opinion amongst the Roma that they cannot find employment due to their nationality. 
At the same time, by actively working on increasing the employment rate of the Romani population, the Association regularly submits bids for public works, which is a system for including the Roma in working on keeping their settlement clean and ensuring proper waste management in general, thus improving the quality of life in the Romani community, which presents a big step in developing awareness on the importance of hygiene. Since in 2006 60\% of Roma of legal age on the territory of the Republic of Croatia had health insurance, the obtained result of $80 \%$ is undoubtedly an indicator of progress $(10,11)$.

Spatial management in Romani settlements is another important activity of the Association, especially as Romani settlements in Sisak are mostly located within construction areas, but without communal infrastructure. For the purposes of repairing and legalizing the Romani settlement in Capraške poljane, direct and constant appeals of the Association to the town administration and to the Government of the Republic of Croatia in 2012 led to 50 families being provided with electricity free of charge, which is one of the praiseworthy steps forward in solving the aforementioned problem. The Association pays particular attention to the elderly and disabled, who due to poverty cannot realize their rights to fulfil basic needs, such as going to the doctor's, and additionally provides support for the protection of youth by organizing common social events or trips to the seaside, encouraging youth to continue their education through the system of socialization and working on preventing underage marriage, which is one characteristic of the Romani tradition and one which needs to be overcome through educating the Romani youth. Certainly, what is crucial is the education of entire families on the importance of personal hygiene, the consequences of becoming sexually active prematurely and education on sexually transmitted diseases (12).

Examination of literature has not provided relevant articles or research on the opinions and attitudes of the Romani population on the importance of hygiene. The authors are aware of a closely connected study on being acquainted with healthy lifestyle habits among Romani students. Mađarić Tuksar (2017) thus states that when researching Romani students, it was discovered that those students are not sufficiently integrated in society and live in relatively inappropriate living conditions. The indicator of that are their undeveloped hygiene habits, which is spe- cifically shown in the said study. In order to solve this burning issue, education of both parents and students needs to be performed by school institutions and healthcare workers (13). Taking into consideration the research of Mađarić Tuksar, a parallel can be drawn between the two studies, with an emphasis on education of the Romani population on the importance of hygiene by continually pointing out the necessity of changing lifestyle habits and with the goal of developing awareness on the importance of hygiene.

\section{Conclusion}

Based on the study conducted and the results obtained, the following conclusions can be drawn:

- Children from Romani families are more often hospitalized due to respiratory problems.

- There are significantly more subjects from Romani families who do not have indoor toilets, indoor plumbing, or bathrooms.

- Children of subjects from Romani families are significantly less frequently hospitalized if the families have indoor plumbing; children who have their own rooms are also less frequently hospitalized for respiratory diseases.

- Children from Romani families are significantly more frequently taken to the doctor's when they are injured or for a regular check-up, and significantly less frequently for medical advice.

- Romani families are less informed regarding the influence of hygiene habits on diseases.

- The level of awareness of the importance of hygiene habits of members of Romani families is at a lower level than those of members of non-Romani families.

All of the above highlights the importance of constant encouragement and education of family members from both Romani and non-Romani populations on the importance of hygiene and strengthening of hygiene habits, but it is even more important to ensure the necessary infrastructure and improvement to living conditions. 


\section{References}

1. Hegeduš Jungvirth M, Klarić D, Rajić Z, Rissi K, Vešligaj G. Zdrava zajednica; očuvanje zdravlja i prevencija bolesti, nezgoda i ovisnosti. Priručnik za voditelje aktivnosti s djecom. Zagreb: Udruga Romi za Rome Hrvatske; 2005. Croatian.

2. Lapat G, Šlezak H. The Roma students' perception of the importance of education. Metodički obzori. 2011;6(2011)1(11):81-93.

3. Ured za ljudska prava i prava nacionalnih manjina. Evaluacija nacionalne strategije za uključivanje Roma u RH. Zagreb: Vlada Republike Hrvatske; 2015. Available at: https://ljudskaprava.gov.hr/UserDocsImages//arhiva// Evaluacija\%20Nacionalne\%20strategije\%20za\%20 ukljucivanje\%20Roma\%20u\%20RH.pdf Croatian.

4. Lapat G. Cjeloživotno učenje Roma u multimedijskom okruženju. [doktorska disertacija] Zagreb: Učiteljski fakultet; 2015. Croatian.

5. Rumbak I. Potrebe/problemi romske populacije u Republici Hrvatskoj: integracija bez asimilacije. Zagreb: Ivan Rumbak; 2003. Croatian.

6. Bakić-Tomić LJ, Lapat G. Projekt Jednake mogućnosti - bolja integracija romske djece u obrazovni sustav Republike Hrvatske. U: Bakić-Tomić, LJ. urednica. Zbornik radova Jednake mogućnosti - bolja integracija romske djece u obrazovni sustav Republike Hrvatske. Zagreb: Udruga za promicanje obrazovanja u Republici Hrvatskoj Kali Sara; 2014. Croatian.
7. Vlada Republike Hrvatske, Ured za ljudska prava i prava nacionalnih manjina. Ostvarivanje prava romske nacionalne manjine: Odgoj i obrazovanje. Available from: https://pravamanjina.gov.hr/nacionalne-manjine/ ostvarivanje-prava-romske-nacionalne-manjine/nacionalni-program-za-rome/odgoj-i-obrazovanje/391 Croatian.

8. Ivičević Ušernik A. Poboljšanje zdravstvenog stanja i zdravstvene zaštite romske populacije u Republici Hrvatskoj. Hrvatski časopis za javno zdravstvo. 2005;1(4):1-4. Croatian.

9. Belak A, Madarasova Geckova A, van Dijk JP, Reijneveld $S A$. Health-endangering everyday settings and practices in a rural segregated Roma settlement in Slovakia: A descriptive summary from an exploratory longitudinal case study. BMC Public Health. 2017;17(1):128.

10. World Health Organization. Roma health in the European Region. Available from: http://www.euro.who. int/en/health-topics/health-policy/health-2020-theeuropean-policy-for-health-and-well-being

11. Obradović S. Gašenje dekade pokazuje da su njeni ciljevi ostvareni: mr. sc. Branko Sočanec. Romi.hr. 2015;1:5-6. Croatian.

12. Udruge Roma Sisačko-moslavačke županije. Udruga za razvoj i bolji život Roma, Sisak. Available from: http:// www.romismz.info/razvoj-i-bolji-zivot/ Croatian.

13. Mađarić Tuksar I. Poznavanje zdravih navika života kod učenika Roma. [diplomski rad] Osijek: Sveučilište Josipa Jurja Strossmayera u Osijeku, Medicinski fakultet, 2018. Croatian. 


\section{HIGIJENSKE NAVIKE I ŽIVOTNI UVJETI ROMSKE POPULACIJE U SISAČKO-MOSLAVAČKOJ ŽUPANIJI}

\section{Sažetak}

Cilj. Pokazati stupanj razvijenosti svijesti o važnosti higijene među romskom populacijom u Sisačko-moslavačkoj županiji. Ispitati postoje li razlike u brizi o zdravlju djece neromske populacije s obzirom na broj hospitalizirane djece romske populacije općenito i s obzirom na respiratorna oboljenja.

Metode. Ispitivanje je provedeno na 100 roditelja trenutačno hospitalizirane djece: 50 pripadnika romske populacije i 50 pripadnika neromske populacije, s pomoću anketnog upitnika posebno konstruiranog za ovo istraživanje. Kategorijski podaci predstavljeni su apsolutnom i relativnom frekvencijom. Numerički podaci opisani su medijanom i granicama interkvartalnog raspona. Razlike u kategorijskim varijablama testirane su Fisherovim egzaktnim testom. Normalnost raspodjele numeričkih varijabli testirana je Shapiro-Wilkovim testom. Razlike numeričkih varijabli između dviju nezavisnih skupina testirane su MannWhitneyjevim U testom.

Rezultati. Iz rezultata je vidljivo da je zbog respiratornih oboljenja jednom u šest mjeseci hospitalizirano znatno više djece (43 \%) iz romskih obitelji. Kod romskih obitelji znatno manje djece hospitalizirano je kod ispitanika koji imaju gradski vodovod u kući. Djecu iz romskih obitelji znatno više vode liječniku kad su ozlijeđena, na redovitu kontrolu, a znatno manje idu liječniku kad samo trebaju neki savjet. U neromskim obiteljima znatno se više djece tušira svaki dan, svatko ima svoj ručnik i bolje razvijene higijenske navike. Iz rezultata je vidljivo da se poznavanje higijenskih navika znatno razlikuje u slučajevima romskih i neromskih obitelji. Zanemarivanje osobnih higijenskih navika djece unutar romskih obitelji ukazuje na problem nedovoljne edukacije roditelja.

Zaključak. Rezultati ukazuju na važnost konstantnog poticanja i educiranja članova obitelji i romske, kao i neromske populacije o važnosti higijene i razvijanju higijenskih navika, posebice unutar obitelji.

Ključne riječi: higijenske navike, respiratorne bolesti djece, romska populacija 